\title{
The Role of Motivation in Human Resources Management: The Importance of Motivation Factors among Future Business Professionals in Libya
}

\author{
Mohamed Z. Mohamed Sherif ${ }^{1}$, Prof. Dr. Umar Nimran, $\mathrm{Ma}^{2}$, \\ Arik Prasetya, S.Sos., M.Si.,Ph.D ${ }^{3}$ \\ Administrative Science, Business Administration/ University Of Brawijaya, Indonesia Malang)
}

\begin{abstract}
The purpose of this study is to find which motivation factors are seen as the most important to motivate Libyan employees in future business. The aim is to analyze findings in the light of existing motivation theories. The knowledge from the theoretical part of this study combined with the results of the research can be useful for managers who deal with freshly graduated employees and for HR professionals who prepare recruitment campaigns focused on attracting future business employees.

The research was based on the online questionnaire survey among various Libyans organization involved in Human resource, 400 samples were distributed online 333 respondents reply back. Respondents were asked to rank motivation factors in the order of their importance and choose three most significant factors motivate them and others as well. The findings of the study revealed that good wages, promotion and growth and interest of work are three most significant factors motivate Libyans employees. Moreover the results of the study suggest that future business professionals are motivated by factors from many different categories. Therefore, the most efficient approach to their motivation should be based solely on intrinsic motivators neither on extrinsic motivators. By being aware of the factors that are the most important for future business professionals companies can meet the challenge of attracting, motivating and retaining them.
\end{abstract}

Keywords: Motivation, Human Resources Management, Business Professionals

\section{Introduction}

The globe is going through an enormous change. Worldwide business is rapidly increasing with the help of modern technologies. These technologies reshaped not only the structure of globe but also bring revolution in the field of business (Dockel, 2003).To be a successful organization/companies have to adopt new technology to lead the organization with new motivated power. Rapidly worldwide changing brings the organization cannot move without management in these days, and management is about time and human resources management (Dockel, 2003).

Human resource is one of the most important parts of an organization. Major activities carried out in the organization are controlled and held by the contribution of human resources. It plays important role in the development of organization beneficially. Stressed that it has same value and important for any organization like marketing, finance, production and organization management and cannot be avoided. The key role of human resource management in any organization is selection and recruitment, planning, training, development program for its employees and motivation of employees to step for improvement in the organization. Sharma (2006) stated that the major task for the human resource is to provide motivated employees to the organization. He further added that motivated employees are life blood for the organization.

Growing numbers of job satisfactions and organization efficiency is the result of human resource motivation. Maintaining the level of motivation of employees in the organization is varied from other activities carried out in the organization and depend on the type of project. Mentioned that work satisfaction and also motivation are considered various in human resources.

Motivation is the strength of the people to make them able to choose specific work, to stay and work hard in the given position. The value of motivating employees is significant at all level of any organization (Kirstein, 2010). This is further explain how an organization motivation is a necessary part for the human resources, beginning from the organization manager must have knowledge and factor influence on the motivation of his sub employees to expect from them to perform well in the organization, goes through the employees to know expectations from their manager in work place end on the professional of human resources who has priority to motivate employee with well design learning and training system. Kovach, (1980) found that companies/ organization more like to have motivated and energetic employees rather than the person with high education but lack of energy. However, due to the different and difficult faces of human behavior it is not an easy job to motivate all of them according to the job expectations. Motivation of employees in any organization has a key role in human resources management where extra salaries/ incentives is the main tools used to 
motivate them. Another author Murphy (1981) suggested that based on nature of the job proportional, wages is the mostly used instrument to motivate the labor in organization.

Past studies showed that the major tool adopted to motivate employees was to offer them extra salary or incentives, but recently it is found that when the companies fall into difficulty in the period of financial crisis, most of the organization go to cut the cost of labor from their salaries and incentives (Nober, 2011). Thus, serious question arises around what other tools can be used to motivate the employees in organizations in an efficient but effective ways. Previous studies showed that there are various approaches to motivate employees and further suggested that employees tend to be motivated if companies give them all necessary needs. (Kirstein, 2010).

The role of human resource and motivation of business people or employees in the companies is different for different culture and economics worldwide. Motivation has been the hot topic since 1930's in human resources management issues but Libya figures out a different both culturally and economically from the rest of the worlds in team of motivating people for future business in the country. Several factors of motivation has been studied in the past for employees but there are not enough researches talking about future employees in the Libya. This study focuses to investigate the future business people which are currently students around the world and influencing motivation factors on human resources. Moreover the aim of this research is to assist human resources management in public and private organization in Libya.

\section{Method}

This section of method will explain adopted procedure for collection of primary data to achieve the aims and objectives of the study, data will further analyzed by using SPSS (Statistical Package for the Social Sciences) software to obtain results.

\subsection{Sources of Data Collection \\ 2.1.1 Primary Data Collection}

The most important part of this study consist of gathering information via distributed questionnaires among future employees including fresh graduates and newly Libyan employees in any organization in Libya. In this kind of survey study respondents of the questionnaire will be Libyan national and will ask them to rank all important factors which motivate them for future business. The questionnaire will distribute among respondent by two means; first option is to send questionnaires to the respondents by emails on different organizations in Libya and to request them to fill up the questionnaire as soon as possible and return back. This way one can save time and cover large group of people in a short period of time. On other hand may be response rate is not so fast but number of response will observer within given specific period.

The second option is to distribute among them by hand, in this case students will be asked to rank all the important factors to motivate them in future business in Libya. Collected samples of data will further analyzed by using computer software to obtain results.

\subsubsection{Secondary Data Collection}

The initiative of this research is collection of secondary data from past studies regarding motivation theories and important factors. Literature consist of various authors views about motivation practices, theoretical analysis and their findings of motivation factors. Access to the secondary data and comprehensive study of various books from library, internet browsing, published research papers and newspaper articles on employee's motivation were study to design literature review and collect secondary data. Main goal of gathering secondary data is to achieve objectives and investigate research questions to come up with moderate and specifically proved answers.

\subsection{Questionnaire Design}

To design questionnaire respondents will inform about the aims and objectives of the questionnaire and provided information will be confidential use only for this research study. Questionnaire will consist of three parts; first part will consist of demographic questions of about five to eight questions and second part will consist of about fifteen questions to ask respondent to rank motivation factors according to their importance in work place. Followed second part another three to five main motivation factors will be asked to choose significant of motivation factors. Lastly open ended questions will be added to ask responded to answer additional other motivational factors. The internet based questionnaire has exactly the same form as the paper based questionnaire. There is the same order of questions and the same graphic design. The questionnaire will be distributed among Libyan student and employees in Libya. 


\subsection{1 (Questionnaire)}

The decision to investigate following factors derived from literature review were part of the questionnaire used in this study. The factors investigated were:

$>$ Sufficiency wage;

$>$ Job Security;

$>$ Interesting Work;

$>$ Promotion and growth in the organization;

$>$ Full appreciation of work done;

$>$ Open communication;

$>$ Participation in goal setting.

$>$ Freedom to plan and execute work independently;

$>$ Feeling of being well informed and involved;

$>$ A good match between your job requirements and your abilities and experience;

$>$ A good working Condition (such as light, temperature, cleanliness, low noise level);

\subsubsection{Population of the Study}

As discussed in above the paragraph Libyan employees and university students will be the population of this study. Randomly selected there are 400 Libyan students and employees including senior staff as well answer the questionnaires.

\subsubsection{Sample Size}

Total of 400 respondents from Libya were randomly chosen (including university students and employees) requested to answer the questionnaire and ranked the motivation factors to achieve the objectives of the study. According to Glenn (2009) to complete successful and more precious research study sample size must not be less than 212. Similar questionnaire will be produce on Googledocs.com to send link to all managerial staff to fill up the questionnaire online and submit on same link easy and modern way to collect information if we have no access to the people.

\subsubsection{Data Analysis}

The collected samples will be further analyzed by using SPSS software which is convenient to use and fast to get the results. Collected samples will be scanned to know valid and invalid samples. Sometimes respondents have mistaken which make the sample invalid and cannot count as an appropriate sample. Frequency, mean and cross tabulation test will be applied on the data to obtain results. Ranking of the factors will be analyzed based on their high mean value and frequency.

\subsection{Results}

\section{Results And Discussion}

\section{To study whether motivation is self or should be induced;}

To collect primary data for this research question, interview among experts was done. Five experts were interviewed to find the answer for this question and below given table $3 \mathrm{~A}$ shows the answer given by respondents which indicated that motivation among employees need to induced by using different tools.

Table 3A Respondents Interviews and answers

\begin{tabular}{|l|l|l|l|l|l|}
\hline Q.1: Motivation is self or should be induced ( Please elaborate) \\
\hline Name & Age & Job Position & Experience & Date and Time & Answer: \\
\hline Akbar & 53 & HR. Manager & 27 years & $\begin{array}{l}11: 00 \mathrm{am}, \\
2 \mathrm{April} 2014\end{array}$ & $\begin{array}{l}\text { It is self but again we need to induced } \\
\text { among employees, }\end{array}$ \\
\hline Hukom & 41 & Engineer & 12 Years & $\begin{array}{l}03: 30 \mathrm{pm}, \\
2 \mathrm{April2014}\end{array}$ & $\begin{array}{l}\text { Depends on individual and his/her interest } \\
\text { of work if they interested they will } \\
\text { motivatedly work and no need to motivate } \\
\text { them. }\end{array}$ \\
\hline Sakina Kamurdin & 38 & Asst: HRM & 11 Years & $\begin{array}{l}09: 20 \mathrm{am}, \\
3 \text { April 2014, }\end{array}$ & $\begin{array}{l}\text { I personally believe that its self usually I } \\
\text { am working on off days as well to complete } \\
\text { my work, }\end{array}$ \\
\hline Fazin Ali & 45 & Professor & 17 years & $\begin{array}{l}11: 40 \mathrm{am}, \\
3 \text { April 2014 }\end{array}$ & $\begin{array}{l}\text { Basically its depends on individual and } \\
\text { their interest but motivation among } \\
\text { employees need to induced in every step of } \\
\text { job }\end{array}$ \\
\hline Mohd.Ayob & 44 & $\begin{array}{l}\text { Marketing } \\
\text { Manager }\end{array}$ & 16 Years & $\begin{array}{l}\text { 02:45pm, } \\
\text { 3April 2014 } \\
\text { employees by using different motivation } \\
\text { tools }\end{array}$ \\
\hline
\end{tabular}

Source: Primary Data Processed, 2014. 


\section{Identify important factors of motivation in human resources management;}

Following are the important motivation factors found from the previous study of human resources management and these tools frequently use in human resources management to motivate employees in organizations.

1. Sufficiency wage;

2. Job Security;

3. Interesting Work;

4. Promotion and growth in the organization;

5. Full appreciation of work done;

6. Open communication;

7. Participation in goal setting;

8. Feeling of being well informed and involved;

9. Freedom to plan and execute work independently;

10. A Good match between your job requirements and your Abilities and Experience;

11. A good working Condition (such as light, temperature, cleanliness, low noise level);

In this section, many factors have been studied from literature review and asked respondents to tick based on their experience which factor motivate them highly and not motivate them when they are working. In this section we will elaborate each factor with respondents replied and lastly we will conclude for highly motivated factors. Following are the factors asked respondents;

\subsubsection{Sufficiency wage}

Table 3.1 Respondents by Sufficiency wage;

\begin{tabular}{|c|c|c|c|}
\hline & & Frequency & Percent \\
\hline \multirow[t]{4}{*}{ Valid } & Highly Motivated & 75 & 23.8 \\
\hline & Motivated & 232 & 73.7 \\
\hline & Not Motivated & 8 & 2.5 \\
\hline & Total & 315 & 100.0 \\
\hline
\end{tabular}

Source: Primary Data Processed, 2014.

The respondents were asked for the factor of motivation of Sufficiency wage, $73.7 \%$ percent respondents answered Sufficiency wage is the motivation factor and motivate them in working, $23.8 \%$ respondents answered that Sufficiency wage highly motivated them and only $2.5 \%$ respondents said Sufficiency wage not motivate them. From the obtained result table 3.1 and below given graph shows that factor of motivation Sufficiency wage motivate employees in working place.

\subsubsection{Job Security}

Table 3.2 Respondents by Job Security

\begin{tabular}{|c|c|c|c|}
\hline & & Frequency & Percent \\
\hline \multirow[t]{4}{*}{ Valid } & highly motivated & 112 & 35.6 \\
\hline & Motivated & 199 & 63.2 \\
\hline & not motivated & 4 & 1.3 \\
\hline & Total & 315 & 100.0 \\
\hline
\end{tabular}

Source: Primary Data Processed, 2014.

Based on literature review and past studies, job security is one the key factor for employees, in this question respondents were asked to answer how much this factor contribute in motivation, among 315 respondents 199 (63.2\%) respondents said job security motivate them, $35.6 \%$ respondents answered this factors highly motivate them only $1.3 \%$ said not motivated, conclusion job security is one the most contributing factor of motivation among respondents. 


\subsubsection{Interesting Work}

Table 3.3 Respondents by Interesting Work

\begin{tabular}{|c|c|c|c|}
\hline & & Frequency & Percent \\
\hline \multirow[t]{4}{*}{ Valid } & highly motivated & 101 & 32.1 \\
\hline & Motivated & 208 & 66.0 \\
\hline & not motivated & 6 & 1.9 \\
\hline & Total & 315 & 100.0 \\
\hline
\end{tabular}

Source: Primary Data Processed, 2014.

Interesting of work is another important factor of motivation among employees, the study found that $66 \%$ respondents answered that interesting of work motivate them, similarly $32 \%$ respondents said interesting of work highly motivate them but only $1.9 \%$ respondents denied, maximum respondents believed that interesting of work motivate them.

\subsubsection{Promotion and Growth in the Organization}

Table3.4 Respondents by Promotion and Growth

\begin{tabular}{|c|c|c|c|}
\hline & & Frequency & Percent \\
\hline \multirow[t]{4}{*}{ Valid } & highly motivated & 104 & 33.0 \\
\hline & Motivated & 200 & 63.5 \\
\hline & not motivated & 11 & 3.5 \\
\hline & Total & 315 & 100.0 \\
\hline
\end{tabular}

Source: Primary Data Processed, 2014.

From the above table 3.4 and below given graph found that promotion of the employees in the organization is one the important motivation factor, it was found that $63.5 \%$ respondents believed that promotion keep them motivated in the working environment and $33 \%$ believed it is highly motivated for the employees only $3.5 \%$ avoided this factors but conclusion from the obtained results indicated promotion of employees in the organization is important factor.

\subsubsection{Full Appreciation of Work Done}

Table 3.5 Respondents by Appreciation

\begin{tabular}{|c|c|c|c|}
\hline & & Frequency & Percent \\
\hline \multirow[t]{4}{*}{ Valid } & highly motivated & 142 & 45.1 \\
\hline & Motivated & 165 & 52.4 \\
\hline & not motivated & 8 & 2.5 \\
\hline & Total & 315 & 100.0 \\
\hline
\end{tabular}

Source: Primary Data Processed, 2014.

In this questionnaire study, respondents were asked to answer for the factor of full appreciation for the job done at work place as a motivation factors indicate that $52.4 \%$ respondents believed this factors motivate them while $45 \%$ answered full appreciation at work place highly motivate them, in contrast $2.5 \%$ respondent disagree and answered full appreciation not motivate them but in conclusion this is one of the key factor to motivate employees at work place in Libya. 


\subsubsection{Open Communication}

Table 3.6 Respondents by Open communication

\begin{tabular}{|c|c|c|c|}
\hline & & Frequency & Percent \\
\hline \multirow[t]{4}{*}{ Valid } & highly motivated & 130 & 41.3 \\
\hline & Motivated & 176 & 55.9 \\
\hline & not motivated & 9 & 2.9 \\
\hline & Total & 315 & 100.0 \\
\hline
\end{tabular}

Source: Primary Data Processed, 2014.

Open communication in work place is one of the important factors, from the above obtained result table from survey study shows that almost $56 \%$ respondents answer open communication in work place motivate them similarly $41.3 \%$ believed that one of highly motivated factors while $2.9 \%$ respondents said open communication not motivate them in work place but conclusion from the result found that open communication of employees in work place motivate them.

\subsubsection{Participation in Goal Setting}

Table 3.7 Respondents by Participation In goal setting

\begin{tabular}{|c|c|c|c|}
\hline & & Frequency & Percent \\
\hline \multirow[t]{4}{*}{ Valid } & Highly Motivated & 127 & 40.3 \\
\hline & Motivated & 186 & 59.0 \\
\hline & not motivated & 2 & .6 \\
\hline & Total & 315 & 100.0 \\
\hline
\end{tabular}

Source: Primary Data Processed, 2014.

The obtained result for the asked question indicate that a large number of respondents agree and answered participation of goal setting motivate them about $59 \%$ and $40 \%$ respondents highly motivate from participation of goal setting.

\subsubsection{Freedom to Plan and Execute work independently}

Table 3.8 Respondents by Freedom to plan and work independently

\begin{tabular}{|c|c|c|c|}
\hline & & Frequency & Percent \\
\hline \multirow[t]{2}{*}{ Valid } & $\begin{array}{l}\text { highly motivated } \\
\text { Motivated } \\
\text { not motivated }\end{array}$ & $\begin{array}{r}100 \\
209 \\
6\end{array}$ & $\begin{array}{r}31.7 \\
66.3 \\
1.9\end{array}$ \\
\hline & Total & 315 & 100.0 \\
\hline
\end{tabular}

Source: Primary Data Processed, 2014.

Respondents found to more motivated when working independently at work place, the question was asked in research questionnaire $66 \%$ respondents agree with the statement $31 \%$ despondently answered working independently working in organization make them highly motivated instead of working under pressure while only $1.8 \%$ respondents deny this statement. 
The Role of Motivation in Human Resources Management: The Importance of Motivation ....

\subsubsection{Feeling of being well informed and involved}

Table 3.9 Respondents by being well informed and involved

\begin{tabular}{|c|c|c|c|}
\hline & & Frequency & Percent \\
\hline \multirow[t]{4}{*}{ Valid } & highly motivated & 82 & 26.0 \\
\hline & Motivated & 227 & 72.1 \\
\hline & not motivated & 6 & 1.9 \\
\hline & Total & 315 & 100.0 \\
\hline
\end{tabular}

Source: Primary Data Processed, 2014.

Majority of the respondents believe that they feel better when the organization informed and involved them in each activities run in organization, $72 \%$ shows high numbers motivate when involved and informed them well while small number of respondents avoided the statement, they are not found to any interest or for them information and involved in any activity in organization.

\subsubsection{A Good match between your job requirements and your Abilities and Experience}

Table 3.10 Respondents by Good match between job requirements and abilities

\begin{tabular}{|c|c|c|c|}
\hline & & Frequency & Percent \\
\hline \multirow[t]{4}{*}{ Valid } & highly motivated & 91 & 28.9 \\
\hline & Motivated & 217 & 68.9 \\
\hline & not motivated & 7 & 2.2 \\
\hline & Total & 315 & 100.0 \\
\hline
\end{tabular}

Source: Primary Data Processed, 2014.

In the following question, respondents were asked to answer whether the job related to their mood, abilities and expertise motivate them or not. From the obtained result shown in table 3.10 and given graph indicate that $69 \%$ respondents said good match job motivate them similarly $29 \%$ respondents said highly motivate them only small bunch of respondents answered for not not motivated.

\subsubsection{A Good working Condition (such as light, temperature, cleanliness, low noise level)}

Table 3.11 Respondents by Good working Condition

\begin{tabular}{|ll|r|r|}
\hline & Frequency & \multicolumn{1}{|c|}{ Percent } \\
\hline Valid & highly motivated & 131 & 41.6 \\
& Motivated & 181 & 57.5 \\
& not motivated & 3 & 1.0 \\
\hline Total & 315 & 100.0 \\
\hline
\end{tabular}

Source: Primary Data Processed, 2014.

The above given table 3.11 indicate the result for working condition, a large number of respondents answered good working condition motivate them to work at work place about $57 \%$ and $42 \%$ respondents answered for highly motivation when working condition is good small number of respondents are not motivated from working condition.

Depends on individual, what factor motivate him/her more as compared to other is different but collectively after the questionnaire study we came up with the results following motivation factors are more effective to motivate them in Libya, and these factors was also found other researcher in their study as discussed in chapter 2. Sufficiency wage, promotion and growth in the organization and interest of work are found to be effective factors of motivation for Libyan employees.

\section{To determine the motivation level of the employees working in Libya;}

Since 2011, after Qaddafi uncertain situation of the country, this study conclude that current level of motivation among Libya employees is found less because of massive damages of the country. people are not satisfied with currently given wages, unfairness in organization corruption and wrong and uneducated people are the top positions of the organization which indirectly impact on the self esteem of the employees and reduce level of motivation to work. 


\subsection{Factors order Rank and Mean}

Table 3.12 Factors order, Ranks, Mean, and Percentage

\begin{tabular}{|l|c|c|c|}
\hline Motivation Factors & Order Rank & Mean & $\%$ \\
\hline Sufficiency wage & 1 & 2.67 & 89 \\
\hline Promotion and growth in the organization & 2 & 2.61 & 87 \\
\hline Interesting Work & 3 & 2.59 & 86.33 \\
\hline Job Security & 4 & 2.54 & 84.66 \\
\hline $\begin{array}{l}\text { A good match between your job requirements and your abilities } \\
\text { and experience }\end{array}$ & 5 & 2.52 & 84 \\
\hline Open communication & 6 & 2.43 & 81 \\
\hline Full appreciation of work done temperature, & 7 & 2.41 & 80.33 \\
\hline Participation in goal setting & 8 & 2.40 & 80 \\
\hline $\begin{array}{l}\text { A good working Condition (such as light, } \\
\text { cleanliness, low noise level) }\end{array}$ & 9 & 2.39 & 79.66 \\
\hline Freedom to plan and execute work independently & 10 & 2.34 & 78 \\
\hline Feeling of being well informed and involved & 11 & 2.33 & 77.66 \\
\hline
\end{tabular}

Source: Primary Data Processed, 2014.

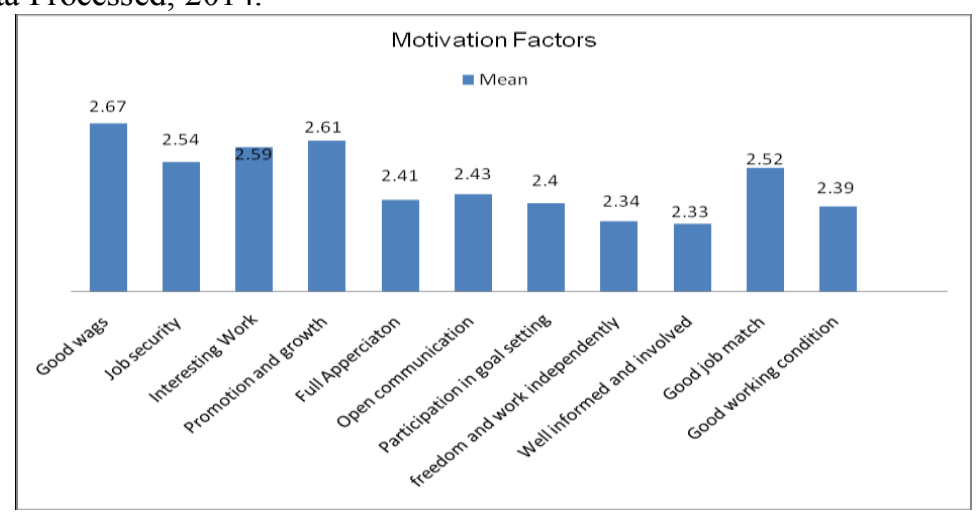

Source: Primary Data Processed, 2014.

Figure 3.1 Motivation factors and Mean

In this study respondents from Libya were asked for motivation factors shown in the above table and graphs indicate ranking based on the mean for each factor. The first most important motivation factor chosen by respondents were Sufficiency wage, above ranking table 3.1 and mean graphs shows that 2.67. this was not only ranking of mean but also if we see the analysis of individual factor above given tables and graphs 4.7 shows $74 \%$ respondents answered that Sufficiency wage motivate them in working. Promotion and growth in the organization was chosen second important motivation factors among the Libyan respondents, study found that employees will be more motivate in working when promotion given on merit based in the organization. The third important motivation factor mean ranked by Libyan respondents in online questionnaire survey study found interest of work. Now the three key motivation factors in Libya was found to be Sufficiency wage, promotion and growth in the organization and lastly third important factor was found interest of work. Other factors followed in following sequence $4^{\text {th }}$ important factor was chosen Job security, $5^{\text {th }}$ good match between job and required abilities ( 6 ) important factor was chosen mostly respondent was open communication (7) full appreciation for work done (8) Participation in goal setting (9) A good working Condition (such as light, temperature, cleanliness, low noise level) (10) freedom to plan and execute work independently (11) feeling of being well informed and involved were put on in the last. The result obtained from this study found that every person has their own criteria for motivation but the three most important of them are (1) Sufficiency wage, (2) promotion and growth in the organization and lastly (3) interest of work highly motivate them in working in Libya.

\section{To elaborate significant strategies to motivate people;}

What strategies need to adopt to motivate people in working place to collect primary data for this research study interview questions was designed and five people were interviewed to get their opinion which is shown in table $3 \mathrm{~B}$.

The findings of interview shows that Sufficiency wage, interest of work and job security is the strategies measurement taken to motivate other people working in organization. 
The Role of Motivation in Human Resources Management: The Importance of Motivation ....

Table 3B: Personal interview

\begin{tabular}{|l|l|l|l|l|l|}
\hline \multicolumn{5}{|c|}{ Q.4: Significant strategies to motivate people } \\
\hline Name & Age & Job Position & Experience & Date and Time & Answer: \\
\hline Akbar & 53 & HR. Manager & 27 years & $\begin{array}{l}11: 00 \mathrm{am}, \\
2 \text { April 2014 }\end{array}$ & $\begin{array}{l}\text { I will say Sufficiency wage on time } \\
\text { motivate employees }\end{array}$ \\
\hline Hukom & 41 & Engineer & 12 Years & $\begin{array}{l}03: 30 \mathrm{pm}, \\
2 \text { April2014 }\end{array}$ & $\begin{array}{l}\text { Due to globalization and insecurity in job } \\
\text { all over the world, Sufficiency wage and } \\
\text { job security will motivate }\end{array}$ \\
\hline Sakina Kamurdin & 38 & Asst: HRM & 11 Years & $\begin{array}{l}09: 20 \mathrm{am}, \\
3 \text { April 2014, }\end{array}$ & Interest of work \\
\hline Fazin Ali & 45 & Professor & 17 years & $\begin{array}{l}11: 40 \mathrm{am}, \\
3 \text { April 2014 }\end{array}$ & Sufficiency wage \\
\hline Mohd.Ayob & 44 & $\begin{array}{l}\text { Marketing } \\
\text { Manager }\end{array}$ & 16 Years & $\begin{array}{l}02: 45 \mathrm{pm}, \\
3 \text { April 2014 }\end{array}$ & Sufficiency wage and interest of work \\
\hline
\end{tabular}

Source: Primary Data Processed, 2014.

\subsection{Discussion}

According to the results presented in this section in above paragraph shows that Sufficiency wage and promotion and growth and thirdly important motivation factor interest of work. The same motivation factors were found in Harpaz (1990) and Linder's (1999) research. Harpaz (1990) also argued in his study Sufficiency wage and interest of work are the most significant factor of motivation among employees. Similarly Linder (1999) found promotion and growth in the organization and Sufficiency wage are important factors. Kovach (1995) in his study also indicated interesting work as the most important factor. Sufficiency wage are so important according to respondents in Libya when analyzed the whole group but it was found that promotion and growth and interest of work is also important. Interesting work seems to be the factor that is indicated as one of the most important in many researches in various settings and environments. Sufficiency wage are seen as very important by some groups of respondents and not by others. It can be assumed that there is something special about the groups that find monetary rewards a crucial motivation factor.

The empirical evidence for this comes from Kovach's (1995) study where the importance of wages was lower in groups of older employees and employees higher in the hierarchy. In the present study there were no significant difference between students who had a job and those who did not. The possible explanation for that might be that time of students' service as employees was too short to change their expectations about work. Current level of motivation of Libyan employees is found Sufficiency wage, promotion and growth. The strategies adopt to motivate employees in Libya are found to offer Sufficiency wage to employees to motivate them in working are one of the most significant strategies. Motivation is self and should be induced to know the answer of this question, interview was design and conduct among bench of expert people in Libya, finding of the interview shows that its depends on individual and his/her interest in job, some employees were found interested to complete given task even in off days as well, which indicate that they are motivated in their work and this motivation is not because of someone or from some source this is self-motivation which came bring naturally no body induced it. Similarly other said motivation among people need to induced because we do not know the given task is according to his interest or not but we motivate them by offering some Sufficiency wage, promotion and job security. This study further concluded that people are not born with the quality of selfmotivation but need to adopt different strategies to motivate them.

This study discussion enclosed with the finding of strategies suggested respondents to motivate people and also justify literature review of the study. Several authors in the past emphasis on the motivation strategies reward which is have connection with productivity. A primary significant strategy to adopt and motivate employees in the organization is fairly increase wages to fulfill one requirement of life. Buller et al., (2012) in his study suggest that money is not only the motivation factor but based on human needs theory it is important to increase the wages of employees they can easily afford and buy the things need for their life. Of course, the salary is most important, but other strategies which enhance and strengthen the purposes of the individual and collective activities can be used. Findings of the primary data collected for this study indicated that Libya culturally and geographically different from the west or the other countries in the world and one of underdeveloped country, the people working and living in this region has different thinking and living stander based on their need priorities it was suggested following some significant strategies which motivate employees are Sufficiency wage, interest of work, promotion in the organization and job security are the strategies can adopt in the organization and motivate people. 


\section{Conclusion}

There are four objectives of this study which have been achieved. The first objective is to study motivation itself, The second is to identify important factors of motivation and their effectiveness, The third is to determine motivation level in employees working in Libya and the last is to draw significant strategies of motivation among people. Based on the results and findings, conclusion for each objective will be drawn in this chapter as follows.

- To determine the first objective of this study, interview was conducted among human resources management experts and their views were recorded. This is concluded that motivation is individual but there are several tools need to be implying to motivate others. According to Akbar (2014, primary data reference) we can motivate and demotivate by offering and rejecting our employees, when we offer Sufficiency wage to our employees we observed that they are happy and work on time motivatedly. On the other hand same task given to other employees without any offer found less motivated.

So we can conclude that self-motivation but implying some tools that can be induced whenever needs. In contrary some employees is found to be self-motivated even they are working on week days (off days) not for extra money but interest of work and need to finish given task on time, here again we can see that interest of work is another tool of motivation which keep motivate employees. Therefore this is further concluded that motivation is self but can be induced by implying some tools.

- Three most important and effective factors was identified in this study to motivate employees working in Libya. Sufficiency wage, interest of work and promotion in organization are three important factors identified by author from randomly online questionnaire survey among Libyan human resources organizations. This study conclude that to motivate Libyan employees working in Libya three significant tools can be adopt and these are offering Sufficiency wage, promotion in organization and lastly interest of work.

- Since 2011, after Qaddafi uncertain situation of the country, this study conclude that current level of motivation among Libya employees is found less because of massive damages of the country. people are not satisfied with currently given wages, unfairness in organization corruption and wrong and uneducated people are the top positions of the organization which indirectly impact on the self esteem of the employees and reduce level of motivation to work.

- As we know that after massive destruction of the country people are found less motivated in their work because of uncertain condition this study further elaborate the strategies of motivation. A primary significant strategy to adopt and motivate employees in the organization is fairly increase wages to fulfill one requirement of life. Secondly promotion of employees should be on merit system and give them full opportunity to come up and show their performance. Lastly this study concluded that based on employees interest in work should be keep in mind before awarding any task. Full apparition on each job was ranked fourth factor in this study further concluded that employees must be appreciated for the task done in the organization.

\section{References}

[1]. D., Murphy. (1981). Incresing Employee Motivation. Cambridge : UK, Cambridge University Press.

[2]. Dockel. (2003). the effect of retention facotrs an organzation commitments: an investigation of high technology investment . Pretoria : University of Pretoria

[3]. Kirstein, M. (2010). The role of motivation in human resources: importance of motivation factors among future business persons . Aarhus : Denmark Aarhus School of Business.

[4]. Kovach. (1987). what motivate employees? workers and supervisor perception and difference . Business Horizons .

[5]. Nobre, F. W. (2011). Technological Managerial and Organizational Core Competences,. Business Scince Reference Publishing, IGI Global, USA, 34-136.

[6]. Sharma, S. (2006). The right way to motivate employees and win their hearts. Retrieved 25-07-2006, from http://www.bpmwatch.com/research/winheart.html

[7]. Murphy, D. (1981). Incresing Employee Motivation, Cambridge University Press, Cambridge, UK, $120-134$ 